\title{
3,4-dihydroxyphenyl acetic acid and (+)-epoxydon isolated from marine algae-derived microorganisms induce down regulation of epidermal growth factor activated mitogenic signaling cascade in Hela cells
}

\author{
Mi Jeong Jo ${ }^{1 \dagger}$, Seong Ja Bae ${ }^{1+}$, Byeng Wha Son ${ }^{2}$, Chi Yeon Kim ${ }^{3^{*}}$ and Gun Do Kim ${ }^{1 *}$
}

\begin{abstract}
Background: Epidermal growth factor receptor (EGFR) is a member of the receptor tyrosine kinase (RTK) family. Epidermal growth factor induces its dimerization and stimulates phosphorylation of intracellular tyrosine residues. Phosphorylation of EGFR is studied for cancer therapy because EGFR regulates many cellular processes including cell proliferation, differentiation, and survival. Hence, down-regulation of EGFR kinase activity results in inhibition of signaling cascades amenable for proliferation and progression of cell cycle.

Methods: In the study, we purified 3,4-dihydroxyphenyl acetic acid and (+)-epoxydon from Aspergillus sp. isolated from marine brown alga Ishige okamurae and Phoma herbarum isolated from marine red alga Hypnea saidana respectively and determined its anti-tumor activities against HeLa human cervical cancer cells.

Results: Two compounds suppressed EGFR activity in vitro with $I_{50}$ values for 3,4-dihydroxyphenyl acetic acid and (+)-epoxydon were 2.8 and $0.6 \mathrm{\mu g} / \mathrm{mL}$ respectively and reduced the viable numbers of HeLa cells. Immunoblotting analysis exhibited that the compounds induced inhibition of cell growth by causing downregulation of the mitogenic signaling cascade, inactivation of P90RSK, and release of cytochrome c from mitochondria.

Conclusions: Results suggest that decreased expression of active EGFR and EGFR-related downstream molecules by treatment with the compounds may results in the inhibition of cell growth and inducement of apoptosis.
\end{abstract}

Keywords: EGFR, HeLa, Marine alga, Ishige okamurae, Hypnea saidana, Mitogenic

\section{Background}

Epidermal growth factor (EGF) receptor (EGFR) is a type 1 receptor tyrosine kinase or member of the ErbB (HER) receptor family [1]. The EGFR receptor is divided into an extracellular ligand-binding domain, which is an anchor domain that spans the membrane, and an intracellular component that activates tyrosine kinase and induces further downstream signaling [2]. After ligand

\footnotetext{
*Correspondence: cykim@gnu.ac.kr; gundokim@pknu.ac.kr

${ }^{\dagger}$ Equal contributors

${ }^{3}$ Department of Dermatology School of Medicine, Gyeongsang National University \& Hospital, Jinju 660-701, Korea

'Department of Microbiology College of Natural Sciences, Pukyong National University, Busan 608-737, Korea

Full list of author information is available at the end of the article
}

activation, the members of the family bind to each other, forming homodimers or heterodimers [3]. It has been shown that EGFR is involved in signaling pathways regulating cellular growth, cell cycling, and differentiation [4]. EGFR is overexpressed in various solid tumors including breast, colorectal, ovarian and non-small-cell lung cancer, and excessive EGFR signaling is associated with the development of a wide variety of benign and metastatic tumors [5]. Furthermore, it is reported that when EGFR is overexpressed, it activates the signaling transduction system, and therefore cancer cells grow more aggressively, and with the invasiveness increasing, the transition occur more easily, affecting negative effects to the survival rate [6]. Therefore knowledge of the 
inhibitory mechanism related to epidermal growth factor (EGF) would assist in searching for targets in cancer therapy [7].

Over the past several decades, many studies on EGFRtargeted therapy in cancer have been performed and numerous targets for anticancer agents have emerged. Especially, monoclonal antibodies (Cetuximab) and tyrosine kinase inhibitors (Gefitinib and Erlotinib) have been developed to inhibit receptor activation $[8,9]$. Currently, people prefer natural products from the ocean or soil rather than chemical compounds made in a laboratory. In recent years, seaweed extracts have been found to have anti-tumor activities [10], and many researchers have identified algae extracts such as fucoidan and carrageenan which demonstrate anti-tumor effects. The results indicate that the extracts from a wide variety of marine algae could suppress tumor activities and restrain the ability of tumors to grow [11,12]. For this reason, many types of algae extracts have been studied and possible reasons that the extracts inhibit a variety of cancers have been elucidated in the field of cell signaling pathways involving apoptosis, death receptor, and cell cycling $[13,14]$.

Marine fungi were reported having a rich profile of biologically active metabolites [15]. The ecological pressures of a unique marine environment may drive the production of new secondary metabolites by microorganisms. As an example, salinosporamide A was isolated from Salinispora tropica, and was found to cause significant proteasome inhibition in clinical trials [16]. Chaetomugilins have been isolated from a strain of Chaetomium globosum originally isolated from the marine fish Mugil cephalus, and exhibited significant growth inhibition against human cancer cell lines [17].

Although a few studies elicited the bioactivities of metabolites from marine microorganisms, there is no report about the marine microorganisms symbiotic with marine algae. The present study was conducted in order to elucidate the mechanism of the antitumorigenic effects of algae derived microorganism extracts, we purified 3,4-dihydroxyphenyl acetic acid from Aspergillus sp. on the marine brown alga Ishige okamurae and (+)-epoxydon from Phoma herbarum on the marine red alga Hypnea saidana, respectively. HeLa human cervical epithelial cancer cells were used in the study as highly express EGFR tyrosine kinase on their surface. We studied the inhibitory effects of the compounds on EGF induced phosphorylation of EGFR in HeLa cells. The results of this investigation may provide new insights into the mechanism of tumor suppression and the possibility for applications in tumor prevention and treatment, because control of the activation of EGFR tyrosine kinase has an important role in tumorigenesis [9].

\section{Results and discussion}

Physiochemical data for 3,4-dihydroxyphenyl acetic acid and (+)-epoxydon from marine algae derived microorganisms

The molecular weight (M.W.) of 3,4-dihydroxyphenyl acetic acid is $168\left(\mathrm{C}_{8} \mathrm{H}_{8} \mathrm{O}_{4}\right)$ (Figure 1). ${ }^{1} \mathrm{H} \mathrm{NMR}\left(\mathrm{CDCl}_{3}\right.$, $400 \mathrm{MHz}) \delta 3.53(2 \mathrm{H}, \mathrm{s}, \mathrm{H} 2-2), 6.64\left(1 \mathrm{H}, \mathrm{s}, \mathrm{H}-2^{\prime}\right), 6.47$ $\left(1 \mathrm{H}, \mathrm{d}, \mathrm{J}=7.5 \mathrm{~Hz}, \mathrm{H}-5^{\prime}\right), 6.63\left(1 \mathrm{H}, \mathrm{d}, \mathrm{J}=7.5 \mathrm{~Hz}, \mathrm{H}-6{ }^{\prime}\right) ;{ }^{13} \mathrm{C}$ NMR (DMSO, $100 \mathrm{MHz}) \delta 173.1$ (s, C-1), 40.2 (t, C-2), 125.6 (s, C-1'), 115.3 (d, C-2'), 144.0 (s, C-3') 145.0 (s, C-4'), 116.6 (d, C-5'), 120.0 (d, C-6'); LREIMS $m / z$ : $168[\mathrm{M}]^{+}(50), \quad 151[\mathrm{M}-\mathrm{OH}]^{+}(29), \quad 123[\mathrm{M}-\mathrm{COOH}]^{+}(100)$, $107[\mathrm{M}-\mathrm{COOH}-\mathrm{OH}+\mathrm{H}]^{+}$(42), 94(26), 77(42).

The molecular weight (M.W.) of $(+)$-epoxydon is 156 $\left(\mathrm{C}_{7} \mathrm{H}_{8} \mathrm{O}_{4}\right)$ (Figure 1$) .[\alpha]_{\mathrm{D}}+71.6^{\circ}$ (c $\left.0.3, \mathrm{MeOH}\right)$; IR (neat) $v_{\max } 3356,1680,1400,1236,1027,903,867 \mathrm{~cm}^{-1}$; UV (MeOH) $\lambda_{\max }(\log \varepsilon) 203$ (3.72), 237 (3.68) nm; CD $(\mathrm{MeOH})(\Delta \varepsilon) 338(+0.95), 245(-1.76) \mathrm{nm} ;{ }^{1} \mathrm{H}$ NMR (400 $\left.\mathrm{MHz}, \mathrm{DMSO}-d_{6}\right) \delta 6.39(1 \mathrm{H}$, dddd, $J=2.7,2.6,2.2,2.1$ $\mathrm{Hz}, \mathrm{H}-3), 4.70$ (1H, ddddd, $J=6.2,2.8,2.8,2.6,2.1 \mathrm{~Hz}$, $\mathrm{H}-4), 5.79(1 \mathrm{H}, \mathrm{d}, J=6.2 \mathrm{~Hz}, 4-\mathrm{OH}), 3.40(1 \mathrm{H}, \mathrm{d}, J=4.2$ Hz, H-5), 3.76 (1H, ddd, J=4.2, 2.8, $2.7 \mathrm{~Hz}, \mathrm{H}-6), 3.96$ $\left(1 \mathrm{H}\right.$, dddd, $\left.J=15.2,5.5,2.8,2.2 \mathrm{~Hz}, \mathrm{H}_{\mathrm{a}}-7\right), 4.07(1 \mathrm{H}$, dddd, $\left.J=15.2,5.5,2.6,2.1 \mathrm{~Hz}, \mathrm{H}_{\mathrm{b}}-7\right), 5.01(1 \mathrm{H}, \mathrm{t}, J=5.5$ $\mathrm{Hz}, 7-\mathrm{OH}) ;{ }^{13} \mathrm{C}$ NMR (100 MHz, DMSO-d 6 ) $\delta 193.9$ (s, C-1), 133.8 (s, C-2), 141.4 (d, C-3), 63.7 (d, C-4), 52.9 (d, C-5), 54.0 (d, C-6), 57.3 (t, C-7); CIMS $m / z$ (rel.int.) $156[\mathrm{M}]^{+}(100), 138\left[\mathrm{M}-\mathrm{H}_{2} \mathrm{O}\right]^{+}(7), 122\left[\mathrm{M}-\mathrm{H}_{2} \mathrm{O}-\mathrm{O}\right]^{+}(2)$, $110\left[\mathrm{M}-\mathrm{CO}-\mathrm{H}_{2} \mathrm{O}\right]^{+}(3)$.

\section{Inhibition of EGFR tyrosine kinase activities}

The inhibitory activity of EGFR tyrosine kinase for two compounds, 3,4-dihydroxyphenyl acetic acid and (+)-epoxydon, were examined in vitro using the AlphaScreen P-Tyr-100 assay system (Figure 2). EGF receptor tyrosine kinase assays were performed at the same conditions to compare 3,4-dihydroxyphenyl acetic acid and (+)-epoxydon. The activity of the soluble EGF receptor kinase domain derived from the cytoplasmic

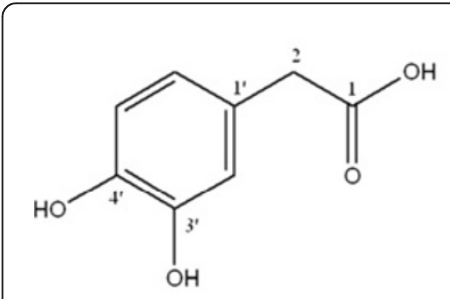

3.4-dihydroxyphenyl acetic acid

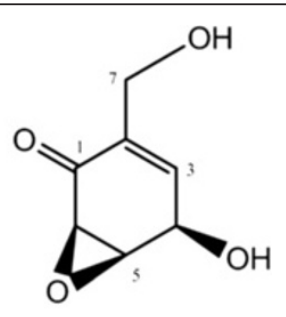

(+)-epoxydon
Figure 1 The effects of the compounds on cell viability. 3,4-dihydroxyphenyl acetic acid and (+)-epoxydon are isolated from Aspergillus sp. derived from marine brown alga Ishige okamurae and Phoma herbarum isolated from marine red alga Hypnea saidana, respectively. 
portion of the human EGF receptor was tested in the assay. The kinase domain is constitutively active and retains its substrate specificities, kinetic constants and autophosphorylation sites without the requirement for ligand-mediated activation. The assay uses the broad spectrum substrate poly [Glu:Tyr] (4:1), and is based on the binding between the phosphorylated polypeptide and the anti-phosphotyrosine antibody (P-Tyr100) conjugated to acceptor beads. Shows that both compounds had inhibitory effect on the activity of EGFR in dose-dependent manner, and the half maximal inhibitory concentrations ( $\mathrm{IC}_{50}$ values) for 3,4dihydroxyphenyl acetic acid and (+)-epoxydon were 2.8 and $0.6 \mu \mathrm{g} / \mathrm{mL}$ respectively.

\section{Inhibitory effects of the compounds on EGF-induced cell growth}

Cell viability assays were performed to examine the effects of each compound on cell proliferation. The cells treated with only EGF were defined as a positive control during experiments, while others were pre-treated with each compound at various concentrations prior to treatment with EGF. The results of the cell viability assay showed that two compounds, 3,4-dihydroxyphenyl acetic acid and (+)-epoxydon, did not inhibit cell growth and proliferation in HEK293 (Figure 3A). On the contrary,

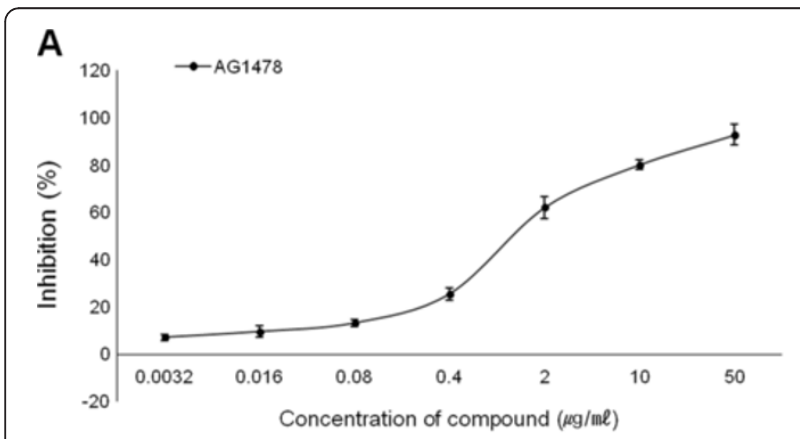

B

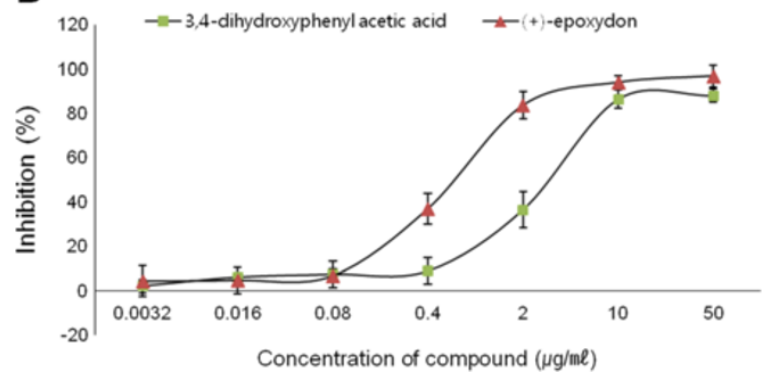

Figure 2 The inhibitory effects of 3,4-dihydroxyphenyl acetic acid and (+)-epoxydon on EGFR kinase activity. The inhibitory effects of the compounds were determined by in vitro kinase assay. The assays were performed followed by the procedures described in Materials and Methods. Values shown in the graphs are mean \pm SDM and were obtained from three independent experiments.
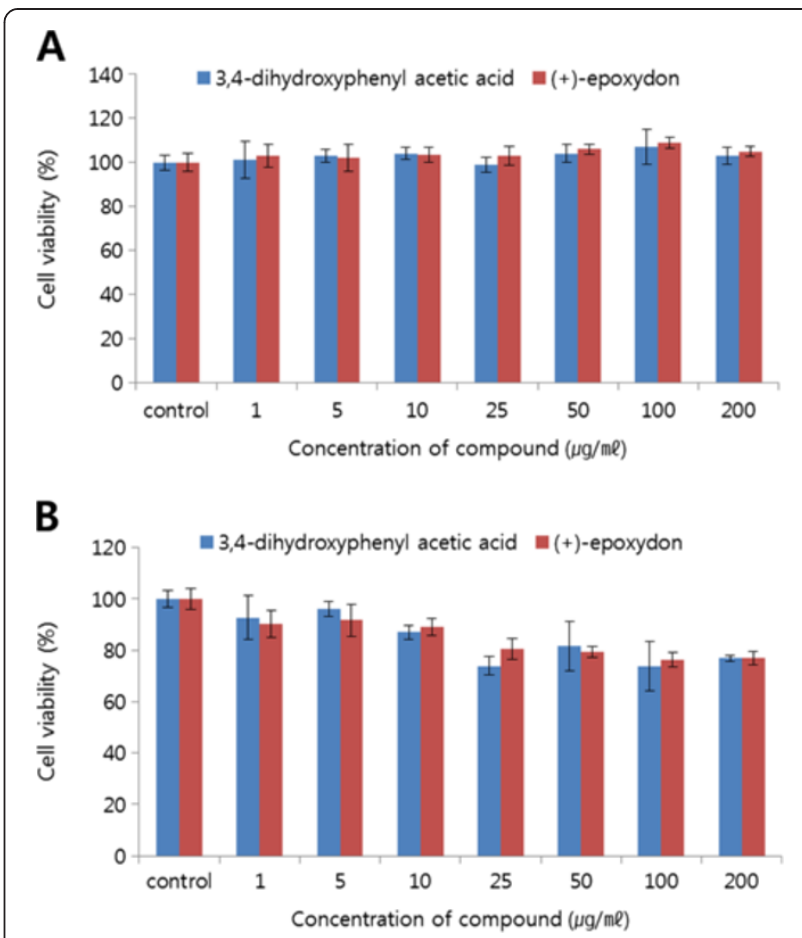

Figure 3 The effects of the compounds on cell viability. The anti-proliferation of HeLa and HEK293 cells were examined using WST-1 ${ }^{\circ}$ solution after treatment with each compound and EGF. The HEK293 (A) and HeLa (B) cells were treated with the indicated concentrations $(0,1,5,10,25,50,100$ and $200 \mu \mathrm{g} / \mathrm{mL})$ of each compound for $40 \mathrm{~min}$, and then exposed to EGF $(10 \mathrm{ng} / \mathrm{mL}$ for 10 min). Values are expressed relative to that of vehicle-treated cells (DMSO), normalized to $100 \%$. Values shown in the graphs are mean \pm SEM and were obtained from three independent experiments.

HeLa cells treated with each compound for 40 min show that the rates of proliferation in HeLa cells are decreased and their inhibition effect was strong on higher concentration (Figure 3B). Additionally, the population of HeLa cells treated with both compounds was reduced during observation under an optical microscope (Figure 4). In comparison to the control cells treated with only EGF, the numbers of cells treated with both compound and EGF were lower than the control numbers. When the cells were exposed to each compound for $48 \mathrm{~h}$, most of cells were dead and floated.

\section{Activation of EGFR tyrosine kinase by EGF as a positive control}

Epidermal growth factor receptor (EGFR) consists of a ligand-binding region and a kinase domain [18]. When the receptor is activated by attachment of an EGF-like ligand on the ligand-binding region, it undergoes a biochemical change to phosphorylate each of the residues on the kinase domain [19]. Especially, phosphorylation of Tyr1068 strongly responds to EGF, and then stimulates mitogenic [Ras/Raf/MEK/extracellular signal-regulated kinase (ERK)] 


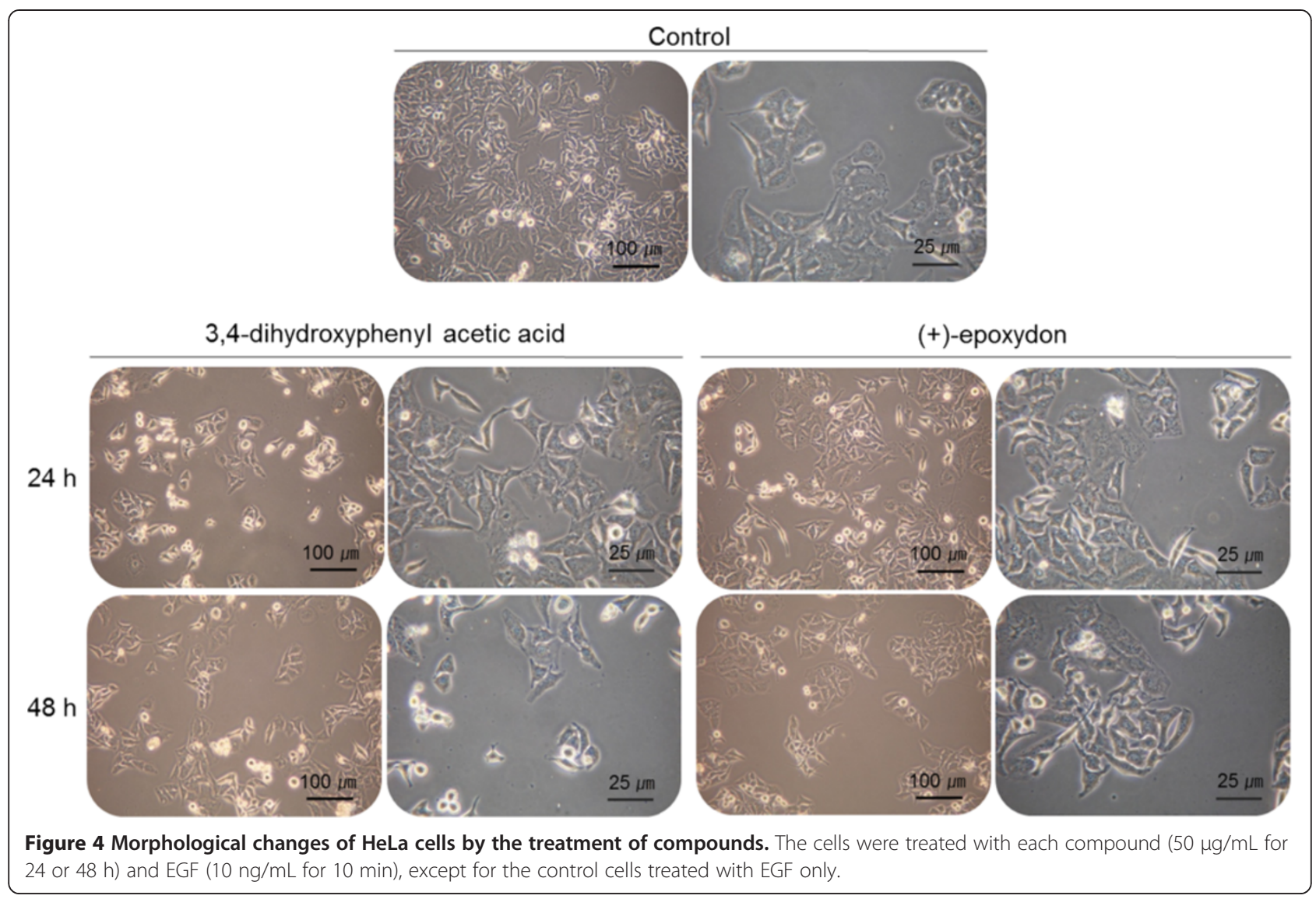

signaling pathways [20]. From Western blot analysis, the expression levels of active EGFR (phospho-EGFR) were stimulated to a greater extent when the cells were treated with EGF (Figure 5). Non-phosphorylated EGFR reflects the total amount of receptor on the cell surface. Thus, it is assumed that the expression level of phosphorylated EGFR depends on treatment with EGF results in its activation even if the amount of receptor exists in the cell is still the same.

\section{Down-regulation of the activated EGFR by the compounds}

EGF plays an important role in the regulation of cell growth, proliferation, and differentiation by binding to its

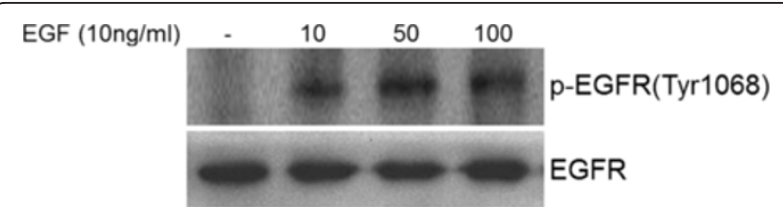

Figure 5 EGFR (phosphorylation of tyrosine) activation induced by EGF. Western blot analysis against phosphorylated form of Tyr1068 and non-phosphorylated form of EGFR was performed to examine the effects of various concentrations of $\operatorname{EGF}(0,10,50,100$ $\mathrm{ng} / \mathrm{ml}$ for $10 \mathrm{~min}$ ) on the activation of EGFR tyrosine kinase in HeLa cells. receptor EGFR [21] and stimulating the associated protein tyrosine kinase activity [22]. Epidermal growth factor receptor (HER1) tyrosine kinase is a recognized target for tumor therapy and anti-cancer drugs have been developed to inhibit receptor activation [23]. Researchers have shown that the receptor was suppressed by tyrosine kinase inhibitors (Iressa) [24], monoclonal antibodies such as Cetuximab, and other compounds [23].

When the cells were treated with each compound before exposure to EGF, the blocking effect was stronger than when not treated (Figure 6). It is believed that EGF binding to the receptor was blocked by those compounds.

EGF (10ng/ml)
3,4-DOPAC (50ug/ml)
(+)-epoxydon (50ug/ml)


Results indicated that treatment of the compounds significantly decreased the phosphorylation of EGFR, but not the EGFR total protein level. In addition, the quantitative changes of the phosphorylated EGFR were assayed by immunofluorescence as shown in Figure 7. The specificity of antibodies to their antigen was used to target fluorescent dyes to phosphorylated EGFR within a cell, therefore allowing visualization of the distribution of the receptor molecule through the sample. As a result, the shapes of cells were expressed in green fluorescent light because immunofluorescence makes use of fluorophores to visualize the location of the antibodies and EGFR exists over the entire cell surface. The cells with EGF (Figures 7A and 7D) had more phosphorylated EGFR compared to untreated cells (Figures $7 \mathrm{~B}$ and $7 \mathrm{E}$ ) and the active functions were interrupted by the 2 compounds (Figures $7 \mathrm{C}$ and $7 \mathrm{~F}$ ).

\section{Inhibition of EGFR-mediated mitogenic signaling}

One of the most important protein kinase cascades activated by tumor promoters, such as EGF, is the mitogenactivated protein kinase (MAPK), induced by the activation of EGFR. Ras is a small guanine-nucleotide binding proteins (G-proteins) cycle between active (GTP-bound) and inactive (GDP-bound) forms [25]. Receptor tyrosine kinases and G-protein-coupled receptors activate Ras, which then stimulates the Raf-MEK-MAPK pathway [26]. Mitogen-activated protein kinases (MAPKs) constitute a widely conserved family of serine/threonine protein kinases involved in many cellular programs such as cell proliferation, differentiation, motility, and death. The p44/42 MAPK (Erk1/2) signaling pathway can be activated in response to a diverse range of extracellular stimuli including mitogens, growth factors, and cytokines $[27,28]$ and is an important target in the diagnosis and treatment of cancer [29]. Upon stimulation, a sequential 3-part protein kinase cascade is initiated, consisting of a MAP kinase kinase kinase (MAPKKK or MAP3K), a MAP kinase kinase (MAPKK or MAP2K), and a MAP kinase (MAPK). MEK1 and MEK2 activate p44 and p42 through phosphorylation of activation loop residues Thr202/Tyr204 and Thr185/Tyr187, respectively. Several downstream targets of $\mathrm{p} 44 / 42$ have been identified, including p90RSK [30] and cytochrome c [31]. Cytochrome c is a well conserved electron-transport protein and is part of the respiratory chain localized to the mitochondrial intermembrane space [32]. Upon apoptotic stimulation, cytochrome $\mathrm{c}$ is released from mitochondria, and this event eventually leads to apoptosis [31].

Therefore, we examined the inhibitory effects of the compounds on the activities of signal molecules in mitogenic signaling cascade. As shown in Figure 8, western blot analysis exhibited that the compounds induced inhibition of cell growth as demonstrated by low expression of signal molecules in the mitogenic signaling cascade and inactivation of p90RSK. Activation of p90RSK by response to growth factor prevents release of

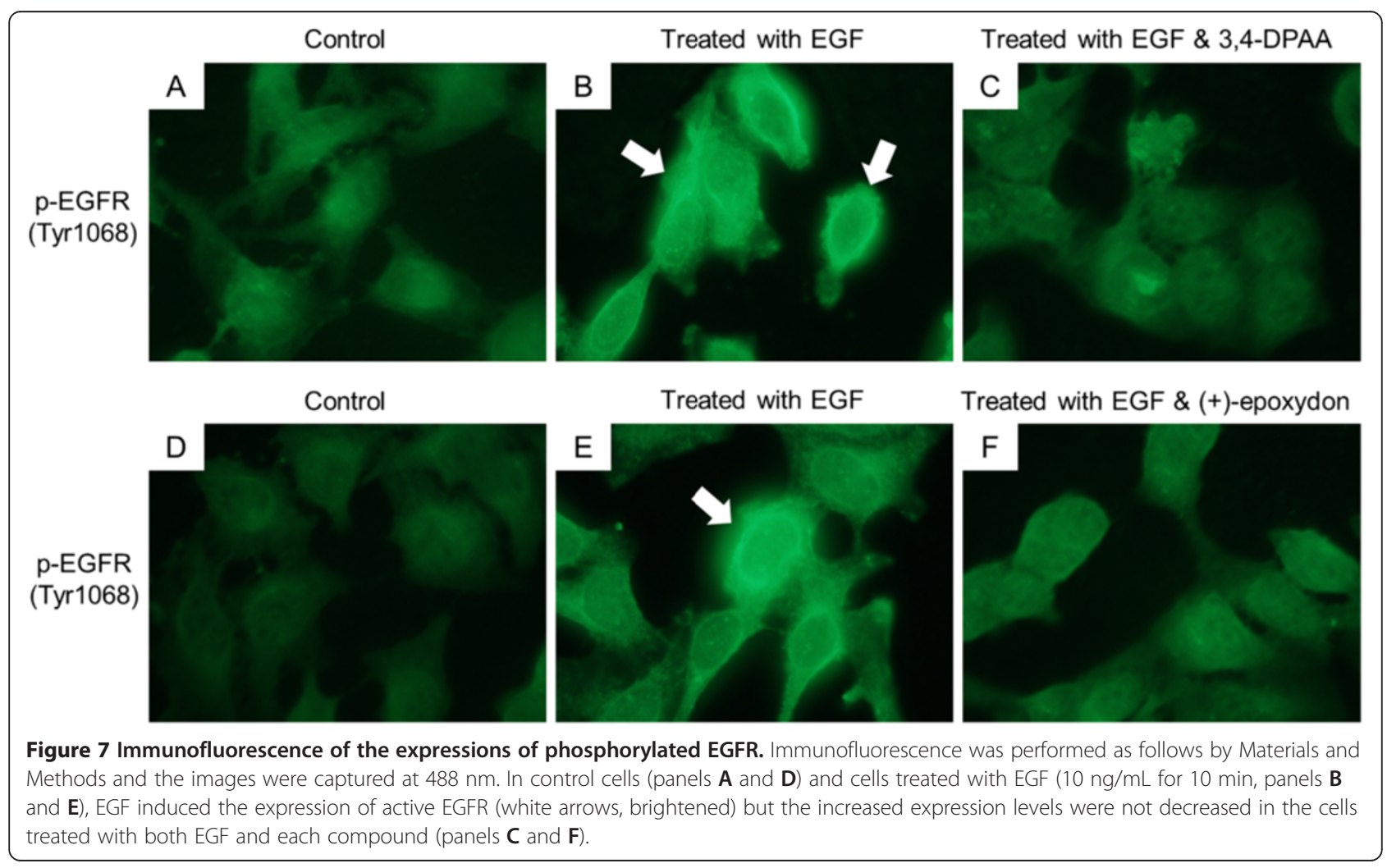




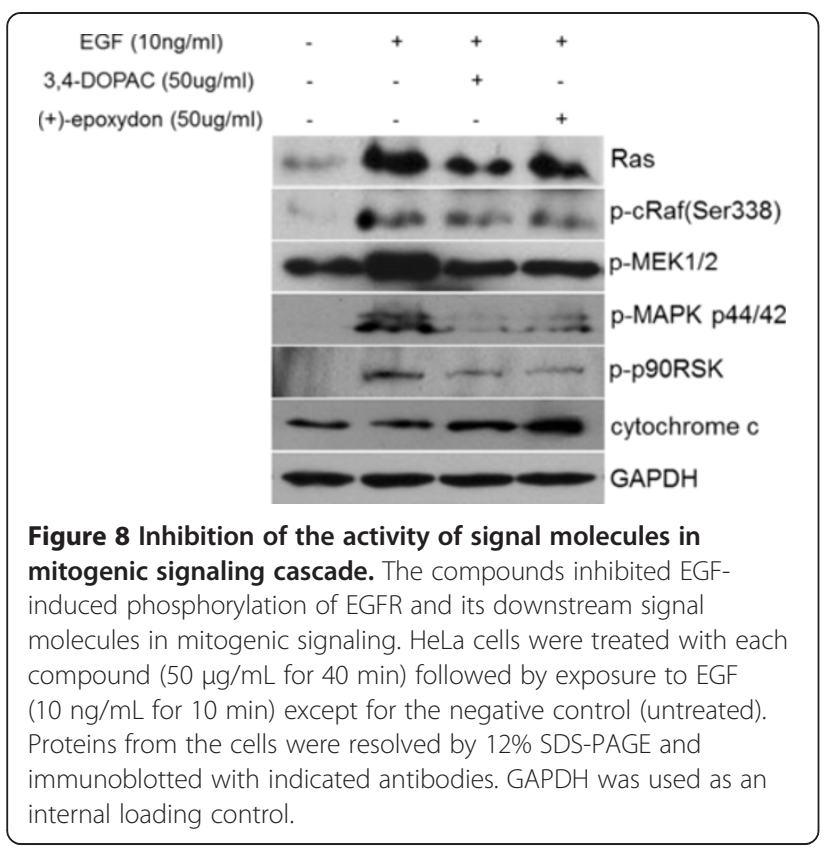

mitochondrial cytochrome $\mathrm{c}$ and progress of apoptosis. The results suggest that decreased expression levels of active EGFR and EGF-related downstream molecules and the possible involvement of p90RSK by treatment with the compounds may affect the inhibition of cell proliferation and induction of mitochondria mediated apoptosis in Hela cells.

\section{Relative inhibitory effect of the compounds to Tyrphostin AG 1478 on the activities of EGFR and EGF-related downstream molecules}

Tyrphostin AG 1478 (AG 1478) is a tyrosine kinase inhibitor and treatment of cells with AG 1478 can block EGFR activation in vivo [33,34]. AG 1478 has been mainly used for laboratory research as an EGFR antagonist. There is increasing evidence to suggest that AG 1478 has anti-tumor activity and significant anti-proliferative effects both in vitro and in vivo [35]. Western blot analysis exhibited that the compound, 3,4-dihydroxyphenyl acetic acid, could down-regulate the expression of phosphorylated EGFR, Ras, phosphorylated MEK, and MAPK, which may be one of the mechanisms by which AG 1478 suppressed cellular invasion (Figure 9). The inhibitory effect of 3,4dihydroxyphenyl acetic acid was similar to or even better than AG 1478. In the case of (+)-epoxydon, the inhibitory effect was not as strong as that of AG 1478, but the expression levels of each molecule were effectively decreased by the compound.

\section{Conclusion}

In this study, we demonstrated that 3,4-dihydroxyphenyl acetic acid and (+)-epoxydon from marine algae reduced expression of the mitogenic signaling cascade and EGFR activation, leading to apoptosis in HeLa cells because EGFR has been indicated to be an important target in cancer therapy.

3,4-dihydroxyphenyl acetic acid is a metabolite of the neurotransmitter dopamine, and can be oxidized by hydrogen peroxide, leading to the formation of toxic metabolites which destroy dopamine storage vesicles in the substantia nigra. (+)-epoxydon is a new secondary metabolite from a marine algae derived fungus. In the present study, we purified 3,4-dihydroxyphenyl acetic acid and (+)-epoxydon from Aspergillus sp. isolated from marine brown alga Ishige okamurae and Phoma herbarum isolated from marine red alga Hypnea saidana respectively and determined its anti-tumor activity against HeLa human cervical cancer cells.

We investigated the antiproliferation effect of two compounds on HeLa cells. Cell viability assay showed that two compounds, 3,4-dihydroxyphenyl acetic acid and (+)-epoxydon, inhibited cell growth and proliferation at $24 \mathrm{~h}$ with $\mathrm{IC}_{50}$ at $21.4 \mu \mathrm{g} / \mathrm{mL}$ and $23.8 \mu \mathrm{g} / \mathrm{mL}$, respectively. The results indicated that two compounds from marine algae derived microorganisms blocked

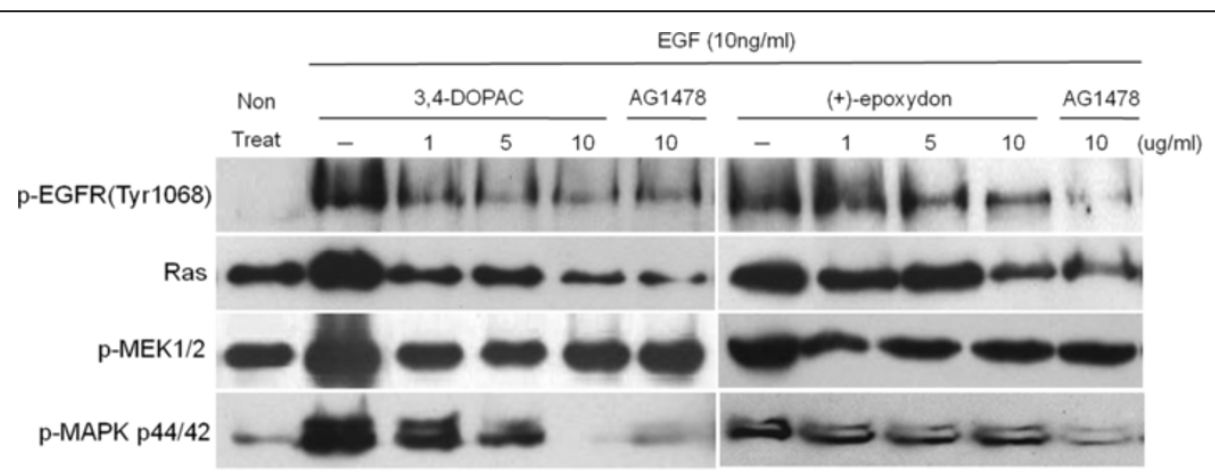

Figure 9 Relative inhibitory effects of the compounds to Tyrphostin AG $\mathbf{1 4 7 8}$ on the activities. HeLa cells were pre-incubated with different concentrations of each compound or AG $1478(10 \mu \mathrm{g} / \mathrm{mL})$ for $40 \mathrm{~min}$ and then stimulated with EGF (10 ng/ml for $10 \mathrm{~min})$. Western blot analysis performed with the indicated antibodies. 
EGF-induced phosphorylation of EGFR, suggesting that both compounds may bind with EGF and prevent the binding of EGF to EGFR. Especially, 3,4-dihydroxyphenyl acetic acid than (+)-epoxydon down-regulated the expressions of phosphorylated EGFR, Ras, phosphorylated MEK , and MAPK to the same degree as AG 1478, which is also a tyrosine kinase inhibitor. The compounds also blocked the phosphorylation of Ras, Raf, MEK, MAPK and p90RSK-induced cell growth and proliferation. In contrast, the release of cytochrome $\mathrm{c}$, which results in apoptosis, was increased by the compounds (Figure 10).

In conclusion, this study demonstrated that the compounds effectively inhibited proliferation and invasion of HeLa cells and suggests that EGFR may be a potential therapeutic agent for cervical cancer.

\section{Methods}

\section{Isolation for 3,4-dihydroxyphenyl acetic acid and} (+)-epoxydon from marine algae derived microorganisms The compound, 3,4-dihydroxyphenyl acetic acid (DOPAC), was isolated from the surface fungus of the marine brown alga Ishige okamurae collected at Uljin, Gyeongbuk province and Geomoon Island, JeonNam province in South Korea. The fungus was then identified as Aspergillus sp. on the basis of morphological evaluation and 18S rRNA analysis (SolGent, Daejeon, South Korea) (similarity 99\%). The fungus was cultured $\left(10 \mathrm{~L}\right.$ for 4 weeks (static) at $29^{\circ} \mathrm{C}$ in a SWS medium consisting of soytone $(0.1 \%)$, soluble starch

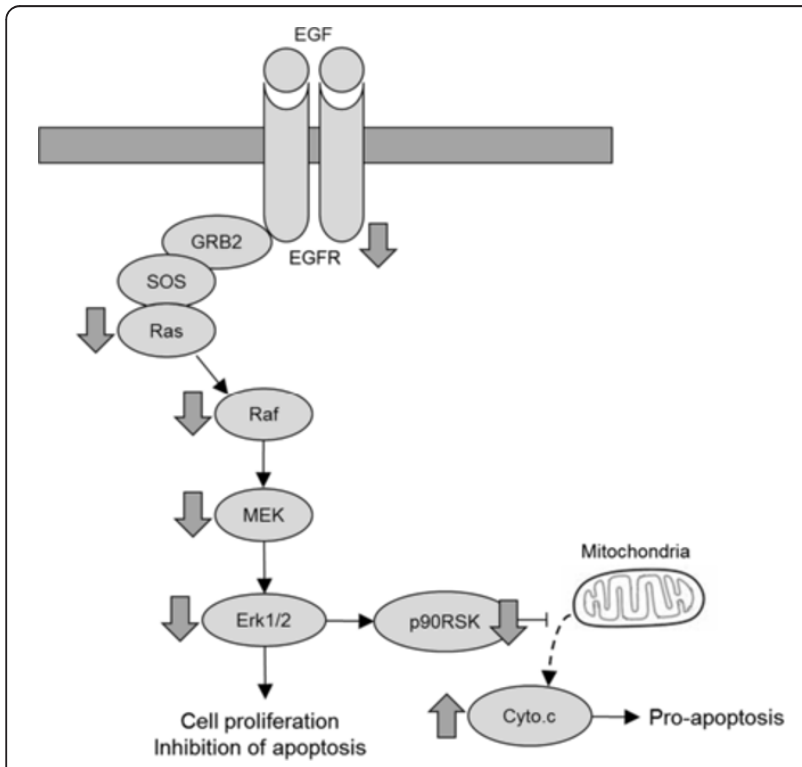

Figure 10 Proposed signaling cascades of the compounds on EGF-induced p44/42 MAPK (Erk1/2) pathways. The compounds inhibited the activities of signal molecules in MAPK pathways and increased release of cytochrome $\mathrm{c}$ from mitochondria. It may results in inhibition of cell proliferation and apoptosis in HeLa cells.
(1.0\%), and seawater (100\%). The resulting broth and mycelia were extracted separately with EtOAc (ethyl acetate) and $\mathrm{CH}_{2} \mathrm{Cl}_{2}-\mathrm{MeOH}$ (methanol) (1:1) to afford the broth extract $(430 \mathrm{mg})$ and the mycelium extract $(1.1 \mathrm{~g})$, respectively. The broth extract showed a radical (DPPH) scavenging activity with an $\mathrm{IC}_{50}$ value of $1.1 \mu \mathrm{g} / \mathrm{mL}$, however, the mycelium extract was inactive. Therefore, broth extracts were subjected to column chromatography on silica gel (n-hexane/EtOAc), and then octadesyl silica (ODS) gel $\left(\mathrm{H}_{2} \mathrm{O} / \mathrm{MeOH}\right)$ to provide 5 fractions. Further purification of fraction-4 containing 3,4-dihydroxyphenyl acetic acid by recycling HPLC, followed by HPLC (C18 Apollo, $\mathrm{MeOH}-\mathrm{H}_{2} \mathrm{O}=3: 2$ ), yielded 3,4-dihydroxyphenyl acetic acid (3.3 mg).

The other compound, (+)-epoxydon, was isolated from the surface fungus of the marine red alga Hypnea saidana collected in Tongnyeong and Yokjee Island, GyeongNam province in South Korea, and then identified as Phoma herbarum on the basis of morphological evaluation and $18 \mathrm{~S}$ rRNA analysis (SolGent, Daejeon, South Korea) (similarity, 99\%). The culture broth and mycelia were separated, and the broth $(10 \mathrm{~L})$ was extracted with ethyl acetate to provide a crude extract $(640 \mathrm{mg})$ which was subjected to silica gel flash chromatography and eluted with n-hexane/EtOAc (5:1), n-hexane/EtOAc (1:1), n-hexane/EtOAc (1:5), n-hexane/EtOAc (1:10), and finally with EtOAc. The collections (30 mL each) were combined on the basis of their TLC profiles to yield 5 major fractions. Medium pressure liquid chromatography (MPLC) of fraction-3 on ODS by elution with $\mathrm{MeOH}$ yielded crude $(+)$-epoxydon $(9.0 \mathrm{mg})$. The isolated crude (+)-epoxydon was further purified by HPLC (YMC ODS-A, MeOH) utilizing a $30 \mathrm{~min}$ gradient program of $50 \%$ to $100 \% \mathrm{MeOH}$ in $\mathrm{H}_{2} \mathrm{O}$ to yield (+)-epoxydon (5.0 mg).

\section{In vitro assay for EGF receptor tyrosine kinase}

The substrate (poly [Glu:Tyr] (4:1)) and the AlphaScreen ${ }^{\odot}$ P-Tyr-100 assay kit (PerkinElmer Inc., Waltham, MA, USA) composed of Donor-streptavidin and AcceptorP-Tyr-100 beads were used for the EGF receptor tyrosine kinase assay. EGFR enzyme purified from human carcinoma A431 cells was purchased from Sigma-Aldrich. The kinase reactions were performed in a mixture of EGFR enzyme, ATP, and biotinylated poly [Glu:Tyr] (4:1) in a kinase reaction buffer (50 mM Tris (pH 7.5), $5 \mathrm{mM}$ $\mathrm{MgCl}_{2}, 5 \mathrm{mM} \mathrm{MnCl}$, $2 \mathrm{mM} \mathrm{DTT}$, and 0.01\% Tween-20). The mixture was incubated for $1 \mathrm{~h}$ at room temperature (RT) and then quenched by addition of detection buffer containing EDTA, Donor-Streptavidin, and AcceptorP-tyr-100 beads. After further incubation for $1 \mathrm{~h}$ at $\mathrm{RT}$, the intrinsic kinetic activities were detected as an AlphaScreen ${ }^{\oplus}$ signal using a Fusion-Alpha microplate analyzer (PerkinElmer Inc.). 


\section{Cell culture and treatment}

Human cervical cancer HeLa cells and human embryonic kidney HEK293 (American Type Culture Collection, Manassas, VA, USA) cells were grown in Dulbecco's Modified Eagle's Medium (DMEM) with high-glucose (HyClone Laboratories, Logan, UT, USA), supplemented with 10\% heat-inactivated fetal bovine serum (HyClone Laboratories) and penicillin-streptomycin (100 $\mu \mathrm{g} / \mathrm{mL}$ penicillin, and 100 units/mL streptomycin) (PAA Laboratories $\mathrm{GmbH}, \mathrm{PA}$, Austria) at $37^{\circ} \mathrm{C}$ with $5 \% \mathrm{CO}_{2}$. Human epidermal growth factor (Sigma-Aldrich, St Louis, MO, USA) was dissolved in media and treated at a final concentration of $10 \mathrm{ng} / \mathrm{mL}$. Each compound was reconstituted with DMSO to $10 \mathrm{mg} / \mathrm{mL}$ and added to the culture media to the final concentration specified in the test. The same concentration of DMSO was added to the control dishes. HeLa cells were treated with $50 \mu \mathrm{g} / \mathrm{mL}$ of each compound for $40 \mathrm{~min}$ and then treated with $10 \mathrm{ng} / \mathrm{mL}$ of EGF for $10 \mathrm{~min}$, except for control cells.

\section{Cell viability assay}

To estimate the effects of the compounds on cell viability, HeLa and HEK293 cells were seeded $\left(1 \times 10^{4}\right.$ cells $/ \mathrm{mL}$ ) in 96 -well plates in $100 \mu \mathrm{L}$ of DMEM-10\% FBS and cultured for $24 \mathrm{~h}$ at $37^{\circ} \mathrm{C}$ in a $5 \% \mathrm{CO}_{2}$ incubator. After incubation, the HeLa and HEK293 cells were treated with two compounds $(0,1,5,10,25,50,100$ and $200 \mu \mathrm{g} / \mathrm{mL}$ ) for $40 \mathrm{~min}$, and then exposed to EGF $(10 \mathrm{ng} / \mathrm{mL})$ for $10 \mathrm{~min}$. After treatment, $10 \mu \mathrm{L}$ of EZCytox Cell Viability Assay solution WST-1 ${ }^{\bullet}$ (Daeil Lab Service, Jong-No, Korea) was added to each well, and the cells were then incubated for $3 \mathrm{~h}$ at $37^{\circ} \mathrm{C}$ in a $5 \% \mathrm{CO}_{2}$. Absorbance was measured at $460 \mathrm{~nm}$ with an ELISA reader (Molecular Devices, Sunnyvale, CA, USA).

\section{Protein extraction and western blotting}

HeLa cells were cultured with each compound for 40 min and then treated with $100 \mathrm{ng} / \mathrm{mL}$ of EGF for 10 min. The cells were then washed twice with cold-PBS, harvested and lysed with lysis buffer [50 mM Tris-Cl (pH 7.5), $150 \mathrm{mM} \mathrm{NaCl}, 1 \mathrm{mM}$ DTT, 0.5\% NP-40, 1\% Triton X-100, 1\% deoxycholate, $0.1 \%$ SDS containing proteinase inhibitors (PMSF, EDTA, Aprotinin, Leupeptin, Prostatin A, Intron Biotechnology, Gyeonggi, Korea)]. The lysates were shaken on ice 6 times every $5 \mathrm{~min}$ and centrifuged at 14,000 rpm for $20 \mathrm{~min}$ at $4^{\circ} \mathrm{C}$. Using bovine serum albumin (BSA) as a standard, the Protein Quantification Kit (CBB solution ${ }^{\circledR}$ ) (Dojindo Molecular Technologies, Rockville, MD, USA) was used for determining the concentration of whole cell lysates. Each protein was resolved by $12 \%$ sodium dodecyl sulfate-polyacrylamide gel (SDS-PAGE) and then transferred onto nitrocellulose membranes (PALL Life Sciences, Pensacola, MI, USA). The membranes were blocked with phosphate buffered
saline-Tween-20 (PBST: $135 \mathrm{mM}$ sodium chloride, $2.7 \mathrm{mM}$ potassium chloride, $4.3 \mathrm{mM}$ sodium phosphate, $1.4 \mathrm{mM}$ potassium dihydrogen phosphate, $0.5 \%$ Tween-20) containing $5 \%$ skim milk for $2 \mathrm{~h}$ at RT and hybridized with the appropriate primary antibody (anti-EGFR (pY1068), anti-EGFR, anti-Ras, anti-c-Raf (pS338), anti-MEK 1/2 (pS217/221), anti-MAPK p44/42 (pT202/204), anti-p90RSK (pS380), anti-cytochrome c, anti-GAPDH (Cell Signaling Technology Inc., Danvers, MA, USA)) for overnight at $4^{\circ} \mathrm{C}$. Protein bands were visualized by enhanced chemiluminescent (ECL) detection solution (Pierce, Rockford, IL, USA) after hybridization for $1 \mathrm{~h}$ with the horseradish peroxidase (HRP)-conjugated secondary antibody from rabbit or mouse (Cell Signaling Technology Inc.).

\section{Immunofluorescence of the phosphorylated EGFR}

HeLa cells were incubated on cover glass-bottom dishes (SPL Lifesciences, Gyeonggi, Korea) in DMEM with high-glucose containing FBS (10\%) and penicillinstreptomycin. The cells were fixed with $4 \%$ formaldehyde (Junsei Chemical Ltd., Japan) for $15 \mathrm{~min}$ at RT and then blocked for $1 \mathrm{~h}$ in $5 \%$ normal serum based on the host primary antibody. After removing the blocking buffer, cells were incubated with $0.1 \mu \mathrm{g} / \mathrm{mL}$ of anti-EGFR (pY1068) overnight at $4^{\circ} \mathrm{C}$ and then washed 3 times in cold PBS followed by incubation for $1 \mathrm{~h}$ with $0.1 \mu \mathrm{g} / \mathrm{mL}$ of anti-rabbit IgG $(\mathrm{H}+\mathrm{L})$, and $\mathrm{F}(\mathrm{ab}$ ) fragment (Alexa Fluor 488 conjugate) (Cell Signaling Technology Inc.). After washing, the stained cells were mounted with Prolong Gold Antifade Reagent (Invitrogen, Eugene, OR, USA) and then observed under a Nikon ECLIPS 50i microscope equipped with a charged-coupled device (CDD) camera (Nikon, Tokyo, Japan). Images were captured and processed with High-Content Analysis Software (Cambridge Healthtech Institute, Needham, MA, USA).

\section{Statistical analysis}

The statistical significance of the differences between the values of compound-treated and non-treated groups was determined by GraphPad Prism 5.0. The results are expressed as mean values \pm standard deviations of the mean (SDM). Every untreated control group and treated group was measured in differences by t-tests. $(p<0.05$ was considered significant). The experiments were performed in triplicates and at least three times each. In case of no error bar in the graph, the variation of values is infinitesimal and thus, the bars are hidden behind.

Competing interests

The authors declare that they have no competing interests.

\section{Authors' contributions}

MJ, SJ, BW, CY and GD participated in the study design, data collection, and data analysis and drafted the manuscript. MJ, SJ and GD participated in the data analysis and drafted and revised the manuscript. All authors read and approved the final manuscript. 


\section{Acknowledgements}

This research was supported by the National Research Foundation of Korea Grand funded by the Korean Government (KRF-2008-314-F00048).

\section{Author details}

Department of Microbiology College of Natural Sciences, Pukyong National University, Busan 608-737, Korea. ${ }^{2}$ Department of Chemistry College of Natural Sciences, Pukyong National University, Busan 608-737, Korea. ${ }^{3}$ Department of Dermatology School of Medicine, Gyeongsang National University \& Hospital, Jinju 660-701, Korea.

Received: 5 December 2012 Accepted: 21 May 2013

Published: 25 May 2013

\section{References}

1. Casalini P, Iorio MV, Galmozzi E, Menard S: Role of HER receptors family in development and differentiation. J Cell Physiol 2004, 200:343-350.

2. Grunwald V, Hidalgo M: The epidermal growth factor receptor: a new target for anticancer therapy. Curr Probl Cancer 2002, 26:109-164.

3. Yarden $Y$, Sliwkowski MX: Untangling the Erb B signaling network. Nat Rev Mol Cell Biol 2001, 2:127-137.

4. Chen WS, Lazar CS, Poenie M, Tsien RY, Gill GN, Rosenfeld MG Requirement for intrinsic protein tyrosine kinase in the immediate and late actions of the EGF receptor. Nature 1987, 328:820-823.

5. Salomon DS, Brandt R, Ciardiello F, Normanno N: Epidermal growth factorrelated peptides and their receptors in human malignancies. Crit Rev Oncol Haematol 1995, 19:183-232.

6. Arteaga $\mathrm{CL}$ : Epidermal growth factor receptor depedence in human tumors: more than just expression? Oncologist 2002, 7:31-39.

7. De Luca A, Pignata S, Casamassimi A, D'Antonio A, Gridelli C, Rossi A, Cremona F, Parisi V, De Matteis A, Normanno N: Detection of circulating tumor cells in carcinoma patients by a novel epidermal growth factor receptor reverse transcription-PCR assay. Clin Cancer Res 2000, 6:1439-1444.

8. Carmi C, Cavazzoni A, Vezzosi S, Bordi F, Vacondio F, Silva C, Rivara S, Lodola A, Alfieri RR, La Monica S, Galetti M, Ardizzoni A, Petronini PG, Mor M: Novel Irreversible epidermal growth factor receptor inhibitors by chemical modulation of the cysteine-trap portion. J Med Chem 2010, 53:2038-2050.

9. Landriscina M, Maddalena F, Fabiano A, Piscazzi A, La Macchia O, Cignarelli $M$ : Erlotinib enhances the proapoptotic activity of cytotoxic agents and synergizes with paclitaxel in poorly-differentiated thyroid carcinoma cells. Anticancer Res 2010, 30:473-480.

10. Ohigashi H, Sakai Y, Yamaguchi K, Umezaki I, Koshimizu K: Possible antitumor promoting properties of marine algae and in vivo activity of Wakame seaweed extract. Biosci Biotechnol Biochem 1992, 56:994-995.

11. Lee NY, Ermakova SP, Zvyagintseva TN, Kang KW, Dong Z, Choi HS: Inhibitory effects of fucoidan on activation of epidermal growth factor receptor and cell transformation in JB6 Cl41 cells. Food Chem Toxicol 2008, 46:1793-1800.

12. Chen HM, Yan XJ, Mai TY, Wang F, Xu WF: Lambda-carrageenan oligosaccharides elicit reactive oxygen species production resulting in mitochondrial-dependent apoptosis in human umbilical vein endothelial cells. Int J Mol Med 2009, 24:801-806.

13. Palozza P, Torelli C, Boninsegna A, Simone R, Catalano A, Mele MC, Picci N: Growth-inhibitory effects of the astaxanthin-rich alga Haematococcus pluvialis in human colon cancer cells. Cancer Lett 2009, 283:108-117.

14. Sheu MJ, Huang GJ, Wu CH, Chen JS, Chang HY, Chang SJ, Chung JG: Ethanol extract of Dunaliella salina induces cell cycle arrest and apoptosis in A549 human non-small cell lung cancer cells. In Vivo 2008, 22:369-378.

15. Boopathy NS, Kathiresan K: Anticancer drugs from marine flora: An overview. J Oncol 2010, 2011:214186-214203.

16. Feling RH, Buchanan GO, Mincer TJ, Kauffman CA, Jensen PR, Fenical W: Salinosporamide A: a highly cytotoxic proteasome inhibitor from a novel microbial source, a marine bacterium of the new genus salinospora. Angew Chem Intl Ed Engl 2003, 42:355-357.

17. Yasuhide M, Yamada T, Numata A, Tanaka R: Chaetomugilins, new selectively cytotoxic metabolites, produced by a marine fish-derived Chaetomium species. J Antibiot 2008, 61:615-622.

18. Maihle NJ, Baron AT, Barrette BA, Boardman CH, Christensen TA, Cora EM, Faupel-Badger JM, Greenwood T, Juneja SC, Lafky JM, Lee H, Reiter JL,
Podratz KC: EGF/ErbB receptor family in ovarian cancer. Cancer Treat Res 2002, 107:247-258.

19. Perona R: Cell signalling: growth factors and tyrosine kinase receptors. Clin Trans/ Oncol 2006, 8:77-82.

20. Stern DF: Tyrosine kinase signalling in breast cancer: ErbB family receptor tyrosine kinases. Breast Cancer Res 2000, 2:176-183.

21. Carpenter G, Cohen S: Epidermal growth factor. J Biol Chem 1990, 265:7709-1772.

22. Dreux AC, Lamb DJ, Modjtahedi H, Ferns GA: The epidermal growth factor receptors and their family of ligands: their putative role in atherogenesis. Atherosclerosis 2006, 186:38-53.

23. Oliveira S, Schiffelers RM, van der Veeken J, van der Meel R: Downregulation of EGFR by a novel multivalent nanobody-liposome platform. J Control Release 2010, 145:165-175.

24. Moulder SL, Yakes FM, Muthuswamy SK, Bianco R, Simpson JF, Arteaga CL: Epidermal growth factor receptor (HER1) tyrosine kinase inhibitor ZD1839 (Iressa) inhibits HER2/neu (erbB2)-overexpressing breast cancer cells in vitro and in vivo. Cancer Res 2001, 61:8887-8895.

25. Boguski MS, McCormick F: Proteins regulating Ras and its relatives. Nature 1993, 366:643-654

26. Buday L, Downward J: Epidermal growth factor regulates p21ras through the formation of a complex of receptor, Grb2 adapter protein, and Sos nucleotide exchange factor. Cell 1993, 73:611-620.

27. Roux PP, Blenis J: ERK and p38 MAPK-activated protein kinases: a family of protein kinases with diverse biological functions. Microbiol Mol Biol Rev 2004, 68:320-344.

28. Meloche S, Pouysségur J: The ERK1/2 mitogen-activated protein kinase pathway as a master regulator of the G1- to S-phase transition. Oncogene 2007, 26:3227-3239.

29. Roberts PJ, Der CJ: Targeting the Raf-MEK-ERK mitogen-activated protein kinase cascade for the treatment of cancer. Oncogene 2007, 26:3291-3310.

30. Dalby KN, Morrice N, Caudwell FB, Avruch J, Cohen P: Identification of regulatory phosphorylation sites in mitogen-activated protein kinase (MAPK)-activated protein kinase-1a/p90rsk that are inducible by MAPK. J Biol Chem 1998, 273:1496-1505.

31. Liu X, Kim CN, Yang J, Jemmerson R, Wang X: Induction of apoptotic program in cell-free extracts: requirement for dATP and cytochrome $c$. Cell 1996, 86:147-157.

32. Schägger H: Respiratory chain supercomplexes of mitochondria and bacteria. Biochim Biophys Acta 2002, 1555:154-159.

33. Levitzki A, Gazit A: Tyrosine kinase inhibition: an approach to drug development. Science 1995, 267:1782-1788.

34. Fan Z, Lu Y, Wu X, DeBlasio A, Koff A, Mendelsohn J: Prolonged induction of p21Cip1/WAF1/CDK2/PCNA complex by epidermal growth factor receptor activation mediates ligand-induced A431 cell growth inhibition. J Cell Biol 1995, 131:235-242.

35. Busse D, Doughty RS, Ramsey TT, Russell WE, Price JO, Flanagan WM, Shawver LK, Arteaga CL: Reversible G1 arrest induced by inhibition of the epidermal growth factor receptor tyrosine kinase requires up-regulation of p27KIP1 independent of MAPK activity. J Biol Chem 2000, 275:6987-6995.

doi:10.1186/1475-2867-13-49

Cite this article as: Jo et al:: 3,4-dihydroxyphenyl acetic acid and (+)-epoxydon isolated from marine algae-derived microorganisms induce down regulation of epidermal growth factor activated mitogenic signaling cascade in Hela cells. Cancer Cell International 2013 13:49. 